\title{
VÁLTOZÓ KÖNYVTÁR. PROBLÉMA - ELEMZÉS - MÉRLEGELÉS - CSELEKVÉS
}

\author{
FODOR PÉTER \\ Fővárosi Szabó Ervin Könyvtár, főigazgató
}

\begin{abstract}
ABSZTRAKT
A korszerú könyvtár tudástár és információs központ, amely hozzájárul az életminőség javításához, az esélyegyenlőtlenség csökkentéséhez. Szolgáltatásaival növeli az egyén versenyképességét, megfelel a hazai és nemzetközi szakmai elvárásoknak. Alkalmas közösségi és kulturális szabadidős programok lebonyolítására; jól megközelíthető, s 24 órás hozzáférést biztosít. Rendelkezik programmal és képes prioritásokat megfogalmazni. Differenciált szolgáltatásaival használó- és olvasóbarát; hatékony személyzettel rendelkezik. De mi a használói elvárás? Hogyan jelenik meg a kommunikációs és információs technológia a bibliotékákban? Mit jelent a multi-platformos technológia alkalmazása, az akadálymentesség, s milyen kihívásokat rejt a többnyelvűség vagy a távhasználat követelménye? Befolyásoló tényező-e a társadalmi megítélés? Van-e összefüggés a társadalmi hasznosság és a finanszírozás között? Van piacképes szolgáltatása? Törvényben előírható az ún. ingyenes használat, mint állampolgári jog, de ezt ki finanszírozza? S mit tehet ma a könyvtár? Hogyan használhatja fel a rendelkezésére álló múködési forrásokat szigorúan, célirányosan? Milyen alternatív források, finanszírozási eszközök, lehetőségek vonhatók be a könyvtár mûködtetésébe? Mit jelent a feladatorientált szervezet-fejlesztés és a hatékony humánerőforrás menedzsment? Hogyan függ össze a könyvtári stratégia, a könyvtáros pályakép, az életpályamodell? Mik lehetnek a könyvtáros képzés irányai, lehetőségei, gyakorlata? Ezekre, a korszerű könyvtár funkcióit és múködését alapvetően befolyásoló kérdésekre keresi a választ az előadás.
\end{abstract}

A könyvtárosok, a könyvtárak az utóbbi évtizedekben is folyamatosan keresik azokat a megoldásokat, amelyek hozzájárulnak ahhoz, hogy a bibliotékák szolgáltatásai megfeleljenek a használói elvárásoknak. Szinte közhely, hogy a felgyorsult világban nagyon fontos, hogy a kultúraközvetítés e tradicionális intézménye képes legyen proaktivitásra. Miért fontos ez? Fontos azért, mert ma már nem elegendő a jelenségekre reagálni, s az sem elegendő, hogy ha elérünk valamit, elégedetten hátradőljünk, az eredményeken megpihenjünk. Folyamatosan szükség van az intézmény állapotának felmérésére, új ötletek bevezetésére, a szolgáltató könyvtár folyamatos gyakorlatára.

\section{A folyamat és fordulópontjai}

A probléma mint jelenség, jelzés az intézmény, a menedzsment felé, hogy ezt érzékelve erre megoldást kell találni. A folyamat időben lehet igen rövid, de kellő odafigyelés hiányában fáziskésésbe is kerülhetünk. A reagálás gyorsasága, tartalmának minősége komoly presztízsnövekedéssel járhat, ellenkező esetben ugyanakkor jelentős szakmai és megítélési veszteséget okozhat. 


\section{FODOR PÉTER}

Az elemrés folyamata a probléma megoldásához járul hozzá. Ez tekinthető a legnehezebb, legösszetettebb feladatnak. Az elemzés metodikája ugyanis befolyásolja, hogy milyen irányú alternatívákat készítünk el a szakasz végén. A sokféle megoldás kínálata a majdani választást, döntést segítik.

A mérlegelés szakasza azt a felelősségvállalást jelenti, amelynek során mód adódik arra, hogy a javaslatok közül azt válasszuk, amelyik alkalmas a probléma valóságos megoldására. Ismert, hogy ebben a fázisban a gondos mérlegelés látszatát keltő tétovaság éppen a döntés meghozatalát odázhatja el.

A cselekvés során a meghozott döntéshez a megvalósítás teljes feltételrendszerét is biztosítani kell, teljességre törekedve megvalósítani az elhatározott döntést. Ha menet közben kiderül, hogy szükséges a módosítás, akkor annak megtételéhez újra kell elemezni az okokat, mérlegelni a lehetséges, újabb alternatívákat. Vagyis az új döntést korrekciónak tekintve, az eredményesség érdekében kell cselekedni.

Az alábbiakban kísérletet teszünk arra, hogy - a teljesség igénye nélkül - ezekre a kérdésekre keressük a megoldásokat: a változó gazdasági, társadalmi környezetben a bibliotéka helyének, szerepének változásaira milyen válaszok adhatók. Természetesen ezek nem törekednek a teljességre, sokkal inkább a magyarországi könyvtárak működési tapasztalatai alapján tesszük fel kérdéseinket, fenntartva a továbbgondolás lehetôségét.

\section{Mi a korsz̧erü könyvtár?}

A kérdés felvetése koronként megismétlődik. A válasz az adott kor összefüggés-rendszerében, műveltségképében helyezhető el.

Napjainkban a hazai és nemzetközi szakmai körökben megerősödött az a vélemény, hogy az tekinthető korszerű könyvtárnak, amelyik egyszerre tudástár és információs központ, azaz a változó és eltérő használói igényeket képes kiszolgálni. Egyszerre felel meg a hagyományos könyvtárképnek és az IT-világ napi elvárásainak. Különböző adatbázisai révén 24 órás szolgáltatást képes nyújtani, s hozzájárul az életminőség javításához. A téma gazdag irodalma éppen az intézmények sokrétűségét emeli ki, hiszen egyénenként változó elvárás fogalmazódik meg a könyvtárral szemben. Ha sikerül egyénre szabottá tenni a szolgáltatást, akkor a könyvtár képes növelni az egyén versenyképességét, hozzájárulhat a helyi közösségek működéséhez, nyitottsága révén komplex módon képes kulturális szerepkört betölteni, s alkalmas közösségi és szabadidős programok szervezésére, befogadására.

\section{Föbb elvárások a public library-vel szemben}

Az itt számba vett legfontosabb elvárások természetesen számos olyan helyi adottsággal bővíthetôk, amelyek nélkül egy könyvtár kevésbé felelne meg a helyi használói elvárásoknak.

Az első kérdés, hogy hol helyezkeedik el a könyvtár. Ez eléggé változatos képet mutat. Van, ahol a városközpontban található, van, ahol a település peremén, de jó közlekedéssel. Évtizedekkel ezelőtt kívánalom volt, hogy csendes hely vegye körül. Ma már az a fő szempont, hogy tömegközlekedéssel könnyen elérhető legyen. Az utóbbi másfél évtized kifeje- 
zett elvárása - és éppen az olvasók, a használók részéről -, hogy a könyvtár fizikailag és virtuálisan is akadálymentes legyen. Rendelkezzen egyre gyarapodó adat- és információs bázissal. Váljék a település tanulási központjává, adjon módot virtuális könyvtárkénti használatra, olyan szolgáltatásokat biztosítson, amelyekhez mindenki hozzáférhet. Az esélyegyenlőség elve alapján, igény szerint, legyen képes személyre szabott szolgáltatást, kiszolgálást is nyújtani.

\section{A basználói elvárás}

A kulturális szolgáltatások nagy rendszerén belül a könyvtári szolgáltatás a sajátosságai révén van jelen a kultúra-közvetítésben. A könyvtáros, a könyvtár számára meghatározóan fontos annak feltérképezése, hogy a könyvtár olvasói, használói, látogatói mit várnak el a bibliotékától. Ma ennek tárháza a hagyományos felméréstől a napi, interneten történt bejegyzésig igen változatos. Az elvárásnak megfelelni szinte lehetetlen, mert az esetek jelentős részében egyéni ötletek, javaslatok, kritikák fogalmazódnak meg. A válaszadás minden esetben a könyvtár felelőssége és kötelessége.

Az általános tapasztalatok alapján az olvasó, a használó a szolgáltatásokhoz gyorsan, időtől és tértől függetlenül akar hozzájutni. Ugyanakkor jogosan várja el a hiteles tájékoztatást és ő maga is igényt tart arra, hogy tájékozódjon. Éppen ezért fontos, hogy a könyvtárat használó kiszolgálása - az ő elvárásának megfelelően - személyesen és/vagy virtuálisan történjen. Mindezt kulturált körülmények között legyen lehetősége megkapni. Ez egyaránt érvényes a valóságos és a virtuális könyvtár esetében. Éppen ezért megkerülhetetlen kérdés a könyvtárlátogató, az olvasó, a bibliotékát használó és a könyvtáros kapcsolata. A segítség, a kiszolgálás valós tevékenység, amely hozzájárul a könyvtáros és a könyvtár megítéléséhez. Az imageépítés hosszú és nehéz folyamat, lerombolása viszont annál rövidebb idôt vesz igénybe. Jogos a felvetés, hogy konfliktusok esetén kinek van igaza? A válasz erre - a tapasztalatok alapján - a könyvtáros nagyobb toleranciájával adható meg, de a menedzsment feladata a munkatársainak megvédése.

\section{A szolgáltató könyvtár}

A könyvtár szolgáltat, amelyet sokan, sokféleképpen vesznek igénybe. Ehhez minden könyvtár számára szükség van programkészítésre, amely rövidebb és hosszabb távú elképzeléseket fogalmaz meg. Ezen belül szükséges prioritásokat megfogalmazni, hiszen egyszerre nem állhat rendelkezésre anyagi és humáneróforrás. Ez a legnehezebb feladata a menedzsmentnek, hiszen a sokféle jó ötlet, a sokirányú kívánság megfelelő súlyozást kíván. Ezt a folyamatot a munkatársak széles körével együtt gondolkodva, vitázva lehet elindítani. Fel kell készülni a paradigmaváltásokra. Az új vezetési technikák alkalmazása az utóbbi két évtized fejlődésének, fejlesztésének is a követelménye.

A többfunkciós könyvár jelenléte megvalósítja a differenciált szolgáltatás elvét, ugyanakkor természetes, hogy mindez a minőségbiztosítási folyamat részeként épül be a könyvtár mindennapjaiba.

Az állandóan bővülő és változó dokumentumok gyűjteményfejlesztési koncepciót és újfajta gyüjteménymenedzsmentet feltételeznek. 


\section{FODOR PÉTER}

Ahhoz, hogy korszerű szolgáltató könyvtár valósuljon meg, szükséges a múködéshez és a fejlesztésekhez a források biztosítása a fenntartó részéről, amely jól kiegészül a különböző pályázati lehetőségekkel. Ahhoz, hogy a könyvár használó- és olvasóbarát bibliotéka legyen, szakmai megújulásra képes szakemberekre van szükség.

\section{A Fövárosi Szabó Ervin Könyvtár (FSZEK) fejlesztési fordulópontjai}

Az 1. sz. ábra a FSZEK utóbbi két évtizedben végbement fejlesztéseinek részben tartalmi, részben feltételrendszerbeli változásait mutatja be.

Fontos kiemelni, hogy a könyvtár menedzsmentje mindig is fontosnak tartotta a folyamatosságot és folytonos megújulást. E nélkül nem lehetséges minőségi szolgáltatást végezni. Szükséges a fejlesztési koncepciók kidolgozása során a prioritások megfogalmazása.

A FSZEK hálózatfejlesztés keretében 2002-2014 között 11 új könyvtárat épített és létesített, illetve 21 nagy rekonstrukciót és 13 kisebb átalakítást valósított meg. Így a FSZEK - a Központi Könyvtárral együtt - ma 50 könyvtári szolgáltató helyen áll a lakosság rendelkezésére. Ezek anyagi forrását a fenntartó Fővárosi Önkormányzat, a kerületi önkormányzatok, a Nemzeti Kulturális Alap pályázatai, illetve az állami címzett támogatások tették lehetővé.

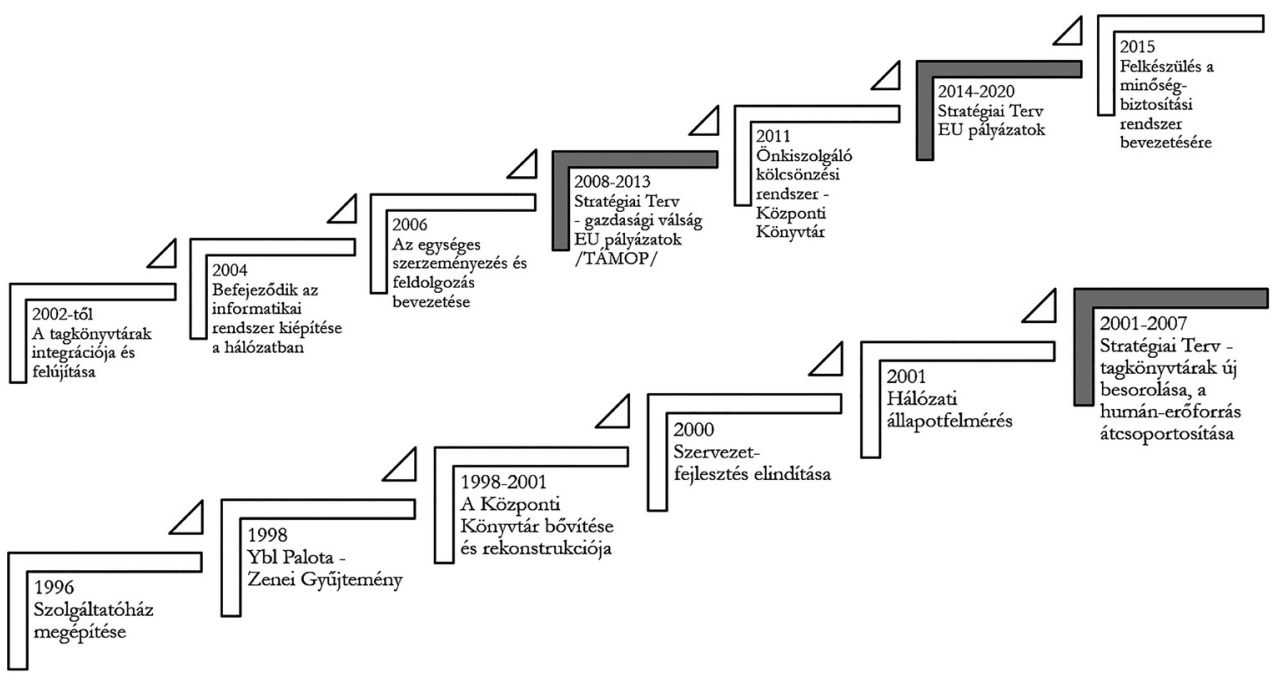

\section{1. ábra: A FSZEK fejlesżésének fordulópontjai}

A FSZEK 2014. évi adatai:

1. 3,2 millió dokumentum

- a harmadik legnagyobb közkönyvtári gyűjtemény Európában

2. 304 ezer regisztrált használó

3. 5,9 millió látogató 
VÁLTOZÓ KÖNYVTÁR. PROBLÉMA - ELEMZÉS - MÉRLEGELÉS - CSELEKVÉS

- személyes 2,3 millió

- távhasználó 3,6 millió

4. 6,7 millió igénybe vett dokumentum

5. 50 könyvtár

6. 423 fó foglalkoztatott

7. 2,246513 milliárd Ft költségvetés

- ebből támogatás 1,628085 milliárd Ft

\section{Mitöl korszerü a Fövárosi Szabó Ervin Könyvtár?}

A FSZEK az ország legnagyobb közkönyvtára, országos szakkönyvtár, a könyvtári rendszer meghatározó intézménye, amely jelen van a nemzetközi és a hazai szakmai közegben.

A könyvtár évszázados tapasztalatokat figyelembe véve végzi munkáját. Folyamatosan figyeli a nemzetközi és magyarországi szakmai trendeket és szemléletet, mindezeket elemzi, mérlegeli a hasznosnak tartott elemeket, azokat gyakorlati munkájába beépíti. Rövidebb-hosszabb távú fejlesztéseit a kidolgozott koncepciók, programok mentén, rugalmasan végzi. Rendelkezik tervezési, megvalósítási tapasztalattal és olyan felkészült, elkötelezett szakembergárdával, amely alkalmas arra, hogy könyvtárszakmai, pénzügyi, műszaki, üzemeltetési kérdések egyidejű mérlegelése alapján végezze munkáját.

A FSZEK az utóbbi másfél-két évtizedben élt a megújulás lehetőségével. Ennek a sokrétű és összetett feladatnak csakis koncepciók kidolgozásával, technológiai váltásokkal tudott megfelelni.

Az eredményesség feltétele volt és ma is az, hogy a humán- és pénzügyi erőforrásokat célszerűen, racionálisan használta, használja fel. Ennek egyik meghatározó eleme, hogy a szakmai kollégák azon a helyen végezzék a munkájukat, ahol erre az intézménynek szüksége van. Ez folyamatos odafigyelést, konzultációt kíván a menedzsment részéről.

A könyvtár sokoldalú partnerkapcsolatai nélkül feladatát nem tudná hatékonyan végezni. Ez megnyilvánul a fenntartóval, a kerületi önkormányzatokkal, a kulturális kormányzattal, a civil szervezetekkel való együttműködésben egyaránt.

Egy könyvtár ismertsége, megítélése folyamatos minőségi szolgáltatást kíván, hogy elismert legyen olvasói és szakmai körökben. Nem lehet egy eredményre hivatkozva „hátradőlni”, mindig szükség van a nyitottságra, a megújulásra.

\section{A könyvtár és a társadalom kapcsolata}

Ebben a fejezetben olyan témakört érintek, amely - tapasztalatom szerint - vitára késztetheti az olvasót. Olyan kérdések felvetését tartom indokoltnak, amelyre a válaszkeresés igénye ma megkerülhetetlen.

A társadalom könyvtárról alkotott képe, megítélése meghatározó ahhoz, hogy hol helyezkedik el a társadalmi hasznosság mezőjében. A különféle időszakokban végzett, olykor eltérő szemléletű felvetések összegzésével az állapítható meg, hogy a könyvtárak az élethelyzet, társadalmi helyzet, szabadidő ráforditás, kulturális kinálat összefüggésében, valamint a kultúraközvetítő intézményrendszerben fontos alapintézmények. 


\section{FODOR PÉTER}

Ha a társadalom meghatározónak tartja a könyvtárat, akkor ennek megfelelően kezelik - helyi és országos szinten - a mindenkori döntéshozók is. Ebben az összefüggésben van szoros kapcsolat a társadalmi megítélés, a hasznosság és a finanszírozás között.

Néhány témakör felvetésével a továbbgondolkodást lehet elősegíteni:

- Könyvtári ingyenes használat. Ez a törvényben előírható mint állampolgári jog. A kérdés az, hogy ezt ki biztosítja, ki finanszírozza? Az állam, az önkormányzat jelentôsen bővülő szerepvállalása a kistelepülések ellátórendszerében ma már komoly előrelépést jelent e tekintetben. Ugyanakkor a gazdasági válságot követóen továbbra sem egyértelmű, hogy a fenntartó és a használó milyen arányban vállal(hat) anyagi terheket.

- A könyvtár alig képes a jelenlegi szerkezetben saját bevételeit növelni. Ha mégis megteszi, ez nem biztos, hogy előnyösen, kedvezően ítéltetik meg.

- Az utóbbi évek izgalmas kérdése, hogy milyen könyvtárra van szükség. Természetesen megjelennek olyan nézetek, hogy az IT világában nincs szükség a hagyományos könyvtárra, hiszen egyre több minden hozzáférhető virtuálisan. A másik nézet továbbra is fontosnak tartja a hagyományos bibliotéka megtartását. A nézetek között van a könyvtáros, a könyvtár. Itt szembe kell nézni azzal a kérdéssel, hogy mi az olvasó, a használó, a látogató elvárása a ma könyvtárával szemben. Ha a felmérések alapján összegeznénk a választ, azt mondhatjuk, hogy egyénileg eltérô igények fogalmazódnak meg: egyszerre kell a könyvtáraknak megfelelni a hagyományos és virtuális könyvtárral szembeni sokszínú igényeknek. Ezért nem mindegy, hogy ismerjük-e a könyvtárhasználók elvárásait és/vagy miért (csak) a mi könyvtárképünket kínáljuk? Az egyes korosztályok másképpen minősítik és értékelik a könyvtárat, másképpen viszonyulnak a tájékozódás világában elérhető gazdag információkhoz. Ezek azok a változások, amelyekre reagálni szükséges, mert könnyen le- és kimaradunk a kulturális szolgáltatás világából.

- Évek óta vita a piacképes szolgáltatás. Ebben a témakörben pro és kontra vélemények is vannak. Ha van ilyen szolgáltatás, miért nem kap szerepet, miért nem mutatjuk be? Ha nincs, akkor miért beszélünk róla? A megoldásokat nyilvánvalóan a kettő között kell keresni. Azonban itt is párbeszéd szükséges, de elsősorban azokkal, akik érintettek, akik ezt elvárják, igénylik.

\section{Mit tehet ma a könyvtár?}

Folyamatosan figyeli, elemzi a könyvtárhasználati szokásokat. A változásokat mérlegeli és rájuk proaktív módon reagál. Ha valamelyik szolgáltatás iránti érdeklődés érzékelhetően csökken, akkor határozottan változtat. A hazai könyvtárak ezen a területen nagyon jó példákat tudnak felmutatni. A külföldi hírek pedig éppen a probléma egyidejűségét és azonosságát erősítik. Kétségtelen, erre nyitottnak kell lenni.

A rendelkezésre álló működési források szigorú, célirányos felhasználása indokolt és szükséges a feladatorientált szervezetfejlesztéshez, a hatékony és rugalmas feladatellátáshoz. Mindehhez racionális, megújuló gazdálkodásra van szükség. A humánerőforrás szakmai továbbképzésével és - megfelelő foglalkoztatás mellett - a frissen végzett és az újonnan belépő kollégák jelenlétével új szemléletet, új lendületet kívánunk adni. 
Egyre nyilvánvalóbb, hogy a fejlesztési forrásokat pályázati úton lehet megszerezni. Az Európai Unió a 2014-2020 közötti időszakra már ismert lehetőségei a korábbi időszakokhoz képest továbbra is hátrányosan érintik Budapestet és Pest megyét. Itt elsősorban az infrastrukturális alapokra lehet gondolni, hiszen a rendező elv a statisztikai GDP, ez pedig csak egy átlag, a valóságot nem tükrözi.

A minőségi szolgáltatás követelménye ma már igen határozottan jelenik meg. Ennek megfelelni kellő felkészüléssel, kellő tapasztalatok birtokában lehetséges. További követelmények:

- Minden szakmának, minden intézménynek szüksége van stratégia késæitésére. Szakmai konszenzus nélkül azonban nehéz stratégiai tervet készíteni és megvalósítani. A szakmai szervezetek (Magyar Könyvtárosok Egyesülete, Informatikai és Könyvtári SzÖvetség) által kezdeményezett konferenciák hatására - stratégiaalkotás, életpályamodell azonban csak lassan formálódnak programmá az elképzelések. Itt is szükséges megerôsíteni a könyvtári terület rendszerszemléletét, mert e nélkül nem lehetséges a cselekvés. - A közösségvezérelte (community-led) könyvtár koncepciójának megjelenítése a hazai bibliotékákban.

- A szolgáltató szemlélet és gyakorlat, mint elvárás érvényesítése.

- Az épületek elhelyezésének és berendezésének szem előtt tartása, figyelembe véve a jó hazai és külföldi trendeket.

- Az új típusú elvárások, a kompetenciák számba vétele.

Ezek együttes végiggondolása minden könyvtár esetében ajánlott. (Különösen érdekes probléma mindez napjainkban a nemzeti könyvtár helyzetének megítélésében. Az új nemzeti könyvtár épületének elhelyezése mellett alapvető kérdés a könyvtár küldetése, szerepvállalása, megítélése a hazai könyvtári rendszerben.)

A Fővárosi Szabó Ervin Könyvtár Budapest kiemelkedő kulturális közintézménye. Megfelel a hazai és nemzetközi trendeknek és a korszerű szakmai követelményeknek. Rendelkezik megújuló szakmai programmal, megújuló szakemberekkel, megújuló intézményrendszerrel. Képes minőségi szolgáltatást nyújtani. A könyvtári rendszer meghatározó intézménye.

\section{Irodalom}

FODOR Péter - HAVAS Katalin: Könyvtári protokoll. Budapest, Könyvtári Intézet, 2007. 86 p. FODOR Péter: Minőség a könyvtárban - korszerú közkönyvtár. = Könyv, Könyvtár, Könyvtáros, 16. évf. 10. sz. 2007. 3-10. p.

A Fővárosi Szabó Ervin Könyvtár fejlesztési koncepciója a 2002-2007 közötti időszakra. Forrás: http://www.fszek.hu/rolunk/szervezet/strategiai_terv/archivum/?article_hid=2394 [2016. január 12.] 


\section{FODOR PÉTER}

A Fővárosi Szabó Ervin Könyvtár stratégiai fejlesztési terve a 2008-2013 közötti időszakra. Forrás: http://www.fszek.hu/rolunk/szervezet/strategiai_terv/archivum/?article_hid=2352 [2016. január 12.]

A Fővárosi Szabó Ervin Könyvtár stratégiai terve 2014-2020 közötti időszakra. Forrás: http:/ [-] www.fszek.hu/rolunk/szervezet/strategiai_terv/?article_hid=27729 [2016. január 12.]

Fodor Péter 1969-ben népművelés és könyvtár, 1973-ban történelem szakon végez, majd 1984ben az ELTE-n doktorál. 1968 óta dolgozik közmûvelődési, múzeumi, könyvtári intézményekben, a kultúrairányítás, igazgatás különböző területein. 1998-tól a Fővárosi Szabó Ervin Könyvtár főigazgatója. 2003-2015 között az Informatikai és Könyvtári Szövetség elnöke. 2005-2010 között az Országos Könyvtári Kuratórium tagja. 1998-2000 között a Nemzeti Kulturális Alap kurátora. 2003-tól könyvtári szakértő. Több évtizedes oktatási tapasztalattal rendelkezik, 2005-tôl a Pécsi Tudományegyetem címzetes docense. 